\title{
TRANSFORMASI MUSIK DALAM BENTUK ARSITEKTUR
}

\author{
Ari Widyati Purwantiasning ${ }^{1}$ dan Ahmad Mubarak Djuha ${ }^{2}$ \\ ${ }^{1}$ Jurusan Arsitektur Universitas Muhammadiyah Jakarta \\ 2Jurusan Arsitektur Universitas Muhammadiyah Jakarta \\ arwityas@yahoo.com amdhadjuha@yahoo.co.id
}

\begin{abstract}
ABSTRAK. Saat berbicara tentang musik dan arsitektur, satu yang dapat didefinisikan pada keduanya, yaitu bahwa keduanya merupakan karya seni. Sebuah karya seni tentunya muncul tidak dengan sendirinya, pengaruh beberapa aspek tentunya menjadi sangat penting dalam proses terbentuknya suatu karya seni. Pengaruh tersebut tidak hanya internal namun juga eksternal. Faktorfaktor eksternal yang dapat mempengaruhi proses terbentuknya suatu karya seni diantaranya adalah manusia, ruang dan waktu. Kedua karya seni musik dan arsitektur sangat dipengaruhi oleh ketiga faktor eksternal tersebut dalam proses perencanaan, perancangan dan implementasi idenya. Keterkaitan musik dan arsitektur sudah banyak diperbincangkan sejak lama, bagaimana dan aspek apa saja yang dapat mengkaitkan keduanya juga sudah lama diperdebatkan. Tulisan ini akan mengkaji tentang benang merah antara musik dan arsitektur, terutama elemen-elemen yang saling terkait di dalamnya, kemudian bagaimana mendiskripsikan dan menganalisis transformasi sebuah musik dalam bentuk arsitektur. Pembahasan masalah ini akan menggunakan metode deskriptif dengan pendekatan deduktif yaitu mengambil sebuah studi kasus dan dianalisa secara umum kemudian dikaitkan secara khusus sesuai dengan teori yang berkaitan dengan musik dan arsitektur.
\end{abstract}

Kata Kunci: transformasi, musik, bentuk, arsitektur

\begin{abstract}
When we discuss about music and architecture, there is a significant thing that should be underlined about it, both of them are artworks. An artwork will not performed by itself, there are some aspects that would become important in the process of artworks' formation. Those aspects were not just an internal aspect but also external one. Some external factors which would effect the process of artworks' formation are human as doer, space and time. Both artworks either music or architecture have been affected by those three external factors in the process of planning, designing and implementing the idea. The relation between music and architecture had been talked since years ago, how and what kind of aspects which will connected both of those artworks had been debated as well. This paper will review about the relation between music and architecture, particularly the elements of each artwork, then how to describe and analyze the transformation of music into architectural form. The discussion of this paper will conduct a descriptive method using deductive approach by taking a case study and analyse generally then will be connected in particular referring to the appropriate theory about music and architecture.
\end{abstract}

Keywords: transformation, music, form, architecture

\section{PENDAHULUAN}

Saat seorang arsitek berusaha menggunakan musik dalam mencari inspirasi, hal ini sudah tidak asing lagi tentunya. Tidak hanya arsitek saja yang menggunakan metode ini, namun banyak pelaku seni yang juga menggunakan musik sebagai salah satu alat untuk menstimulasi munculnya ide-ide cemerlang. Bagaimana memadukan sebuah musik dan arsitektur, mungkin itu yang akan digarisbawahi dalam tulisan ini. Memadukan tentunya tidak hanya memasukkan unsur musik dalam disain, namun bagaimana mengintegrasikan elemen-elemen musik dalam arsitektur, sehingga elemen-elemen dalam musik dapat bersinergi dengan elemenelemen dalam arsitektur. Saat seorang filsuf terkenal Goethe menyatakan bahwa "architecture is a frozen music" yaitu bahwa arsitektur adalah suatu musik yang beku, maka di lain pihak untuk menandingi pernyataan tersebut Quincy Jones menyatakan bahwa "if architecture is a frozen music then music must be a liquid archicture".

Dengan kedua pernyataan tersebut maka tidak dapat dipungkiri bahwa keduanya yaitu musik dan arsitektur sangat erat berkaitan satu sama lainnya. Banyak penelitian yang telah dilakukan dalam mencari kaitan antara musik dan arsitektur, banyak juga perdebatan yang terjadi dalam mencari dan memilih melalui aspek apa sajakah keduanya dapat dicari keterkaitannya. Kedua karya seni tersebut 
memiliki banyak faktor yang dapat dikaitkan satu sama lainnya. [1]

\section{DEFINISI MUSIK}

Saat berbicara tentang musik, harus didefinisikan di sini bahwa musik adalah suatu bunyi yang timbul karena gesekan, ketukan ataupun pukulan yang dihasilkan oleh suatu alat musik atau beberapa alat musik yang dihasilkan oleh satu individu atau beberapa individu yang berbeda-beda berdasarkan preferensi dan referensi dari setiap individu. Hal ini tentunya berkaitan dengan sejarah, budaya, lokasi maupun selera seseorang. Musik juga dapat diartikan sebagai sebuah bentuk seni yang menggunakan media suara. Di dalam musik terdapat beberapa elemen penting seperti pitch (yang mengatur melodi dan harmoni), rhythm (berkaitan dengan konsep tempo, meter dan artikulasi), dinamika dan kualitas sonic timbre dan tekskur. Sebuah musik tidak dapat dipisahkan dari segala elemen tersebut di atas untuk menghasilkan suatu karya seni yang tinggi. [1]

Musik juga dapat dikatakan sebagai rangkaian unsur-unsur harmoni yang tergabung menjadi satu sehingga membentuk suatu melodi berupa lagu. Dalam proses pembentukannya, musik dapat diinterpretasikan setara dengan arsitektur, bagaimana unsur-unsur titik, garis, bidang yang dapat membentuk suatu ruang tertentu sehingga membentuk tempat, seperti yang diuraikan dalam teori Space and Placenya Roger Trancik. [2]

Di lain pihak, musik dapat juga dideskripsikan sebagai suatu bentuk dan alat komunikasi yang unik antar individu, seperti halnya grammar dalam bahasa keseharian. Terkadang hanya individu tertentu saja yang mengerti akan pesan yang disampaikan dalam sebuah lagu. Faktor psikologis sangat berpengaruh dalam hal ini, karena emosional sebuah lagu dapat diterjemahkan dalam liriknya. Apakah lagu tersebut termasuk dalam kondisi yang bersemangat, lelah, sedih, tertekan, marah dan senang, tentunya hal ini tidak jauh berbeda dengan intonasi seseorang saat berbicara dengan orang lain.

Emosi sebuah lagu ini ditunjukkan dalam variabel musik yaitu dinamika, artikulasi, legato dan lainnya. Kecepatan sebuah lagu dinyatakan dalam sebuah tempo. Secara fisik, komponen utama dalam musik adalah bunyi atau suara, tanpa adanya bunyi atau suara maka tidak dapat dikatakan sebagai suatu musik. Bunyi atau suara inilah yang akan mempengaruhi kondisi psikologi seseorang, karena bunyi atau suara dapat memberikan sebuah sensasi atau persepsi bagi seseorang yang mendengarkannya. Dengan musik, seorang pelaku seni yang mendengarkannya akan mendapatkan rangsangan atau stimulus dengan indera pendengarannya, sehingga banyak ide-ide dan inspirasi cemerlang datang karena proses stimulasi ini.

Musik dapat mempengaruhi emosi atau perasaan manusia, baik secara fisik (fungsi tubuh) ataupun psikis (memori, pemikiran, dan persepsi). Two-component theory of emotion, merupakan suatu teori yang menjelaskan bahwa emosi manusia (ketika mendengarkan musik atau kegiatan lain) dapat dipengaruhi oleh interaksi antara komponen fisik dan komponen psikis dari manusia. Komponen fisik menentukan intensitas dari emosi yang ditimbulkan, sementara komponen psikis menentukan kualitas emosi yang timbul. [3]

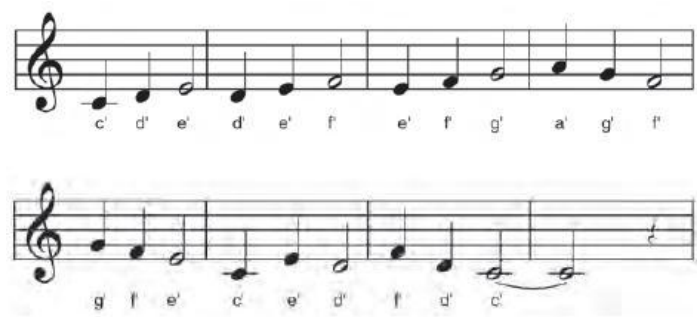

Gambar 1. Contoh melodi dalam musik

Sumber: Seni Budaya dan Ketrampilan Kelas 4 SD, 2013

Seperti saat ini, musik sudah menjadi kebutuhan bagi setiap manusia baik itu laki-laki ataupun perempuan. Berbeda pada saat awal pertama musik dikenal hanya sebagai suatu hiburan semata dan hanya dinikmati pada saat-saat tertentu saja. Sekarang musik menjadi suatu kebutuhan yang vital, karena hampir setiap orang mendengarkan musik setiap harinya, baik itu musik jazz, rock, metal, pop, bahkan dangdut sekalipun semua orang mendengarkannya. Musik sudah menjadi tren atau gaya hidup bagi manusia saat ini, musik juga mampu merubah atau mempengaruhi psikologi seseorang. Orang yang mendengarkan musik rock atau metal dan pop memiliki karakter yang berbeda. Orang yang sering mendengarkan musik rock atau sebut saja musik keras akan lebih cenderung hidupnya sedikit arogan, pemarah, dan terkadang labil. Sedangkan orang yang sering mendengarkan musik pop atau melo akan cenderung lebih teratur, sedikit sensitif, dan tidak suka dengan kekerasan. Begitulah musik sangat mempengaruhi psikologi seseorang. [4] 
Dalam proses terbentuknya sebuah karya seni musik, ada beberapa unsur atau elemen yang mempengaruhi komposisi sebuah musik. Unsur-unsur dasar dalam komposisi musik tersebut merupakan esensi material dari sebuah musik, yaitu melodi, harmoni, irama, dan dinamika. Melodi memberikan musik sebuah soul (nuansa), sedangkan ritme (rhythm) merupakan campuran ekspresi harmoni dan dinamika dengan tempo yang sama. Semua ini diperlukan untuk menciptakan sebuah pola yang lebih dikenal dengan "lagu". [4]

\section{DEFINISI ARSITEKTUR}

Lain halnya dengan musik yang merupakan karya seni yang didasari atas suara dan bunyibunyian, maka arsitektur dapat diartikan sebagai sebuah ilmu merancang bangunan dalam skala mikro maupun makro. Dalam skala mikro arsitektur dapat diartikan sebagai ilmu meruang, dan dalam skala makro tentunya arsitektur dapat dikaitkan dengan ruang kota. Sehingga seorang yang memiliki keilmuan dalam bidang arsitektur yang dikenal sebagai arsitek, dalam arti luas dapat mencakup segala pekerjaan yang berbau merancang dan membangun segala sesuatu dari skala ruang dalam suatu hunian ataupun ruang bangunan sampai dengan skala ruang kota. Dalam kenyataannya, sebuah karya arsitektur mencakup segala hal yang berkaitan dengan konstruksi, fungsi, estetika, ruang, tempat dan keteraturan. [1]

Sementara itu dalam bukunya Architecturally Speaking, Raskin menekankan bahwa arsitektur terdiri dari tiga macam emosi yaitu: emosi yang diinginkan (intended emotion), emosi yang melekat (inherent emotion) dan emosi yang bangkit atau terjadi (evoked emotion). [6]

Ketika sebuah karya arsitektur terbentuk, maka emosi sangatlah berperan penting, seseorang dengan emosi yang hebat akan menghasilkan karya arsitektur yang hebat juga. Sementara bila tidak memiliki emosi sama sekali, maka arsitektur yang dihasilkan juga tidak memperlihatkan emosi apapun, yang terbentuk hanyalah bangunan tanpa ada karakter apapun.

Dalam pembentukan sebuah karya arsitektur, tentunya terdapat berbagai elemen dan unsur pembentuknya. Raskin menguraikan bahwa di dalam ilmu arsitektur, terdapat beberapa elemen dasar yaitu: Gaya (style); Kesatuan (unity); Skala; Ritme; Orisinalitas; Proporsi;
Sekuens; Komposisi; Fungsi; Karakter dan kejujuran. [6]

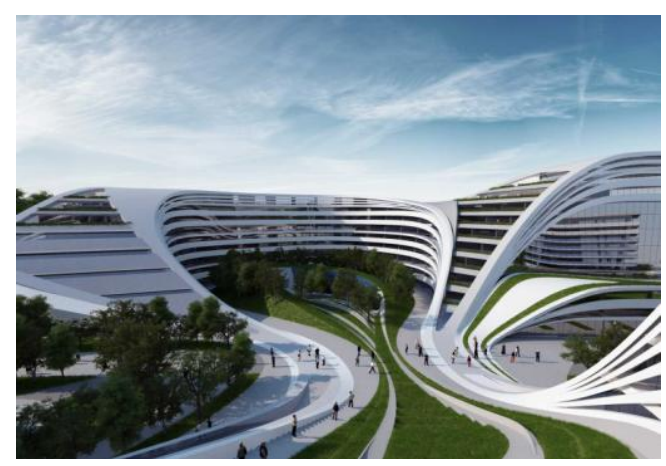

Gambar 2. Contoh karya arsitektur dekonstruksi Sumber: archdaily.com, 2016

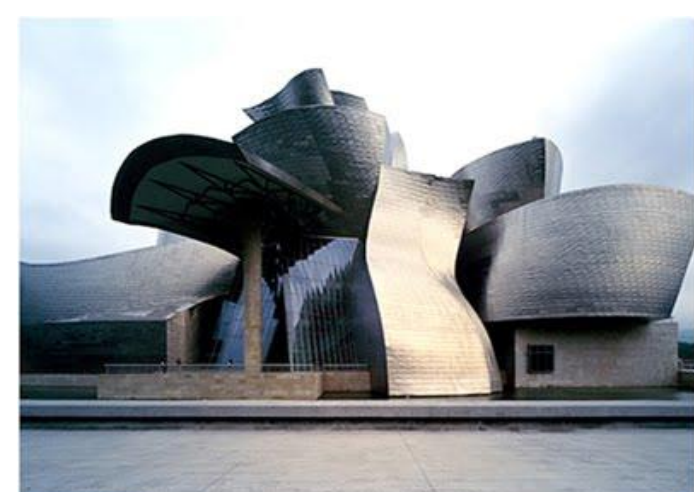

Gambar 3. Contoh karya arsitektur feminin Sumber: aebrudemirci.com, 2016

Dari elemen-elemen dasar di atas, beberapa elemen yang dianggap berkaitan dengan musik adalah elemen dasar komposisi, fungsi, pola dan proporsi. Komposisi dapat didefinisikan sebagai sebuah susunan beberapa macam bentuk yang terjalin menjadi satu kesatuan sehingga terbentuk suatu bentuk baru sesuai dengan kondisi tertentu. Di dalam arsitektur komposisi sangat penting keberadaannya baik dalam pengaturan pola ruang sesuai fungsi dan ergonomi penggunanya. Komposisi juga berkaitan dengan sesuatu yang dilihat dengan kasat mata, seperti fasad bangunan misalnya, dengan komposisi yang tepat, maka bangunan secara estetika akan indah dipandang.

Elemen yang kedua adalah fungsi, yang secara sederhana dapat diartikan sebagai kegunaan. Yaitu sesuatu yang dimaknai sebagai suatu cara untuk memenuhi kebutuhan tertentu, bukan hanya keinginan semata, namun harus sesuai kebutuhannya. 
Sebagai seorang manusia, secara hakikatnya memiliki kebutuhan untuk mempertahankan dan mengembangkan hidupnya. Seperti halnya yang dikatakan dalam teori Maslow bahwa manusia memiliki berbagai kebutuhan dari mulai sandang, pangan, papan, rasa aman, rasa nyaman, kebutuhan sosial, kebutuhan akan penghargaan sampai dengan kebutuhan untuk aktualisasi diri. Kesemua kebutuhan ini tentunya dapat diwujudkan dalam karya arsitektur yang fungsional.

Seperti halnya dalam sebuah frase yang dinyatakan oleh Louis Henri Sullivan yaitu "Form Follows Function" yang dimaknai bahwa fungsi memiliki peranan penting dalam membuat bentuk arsitektur. Form follows function muncul pada awal abad ke-20. Form follows function sering diasosiasikan dengan arsitektur modern dan desain perindustrian. Kalimat ini diartikan sebagai bentuk bangunan atau suatu obyek harus disesuaikan dengan fungsi atau kegunaan dari bangunan itu. Segala rancangan arsitektur terjadi karena adanya suatu fungsi yang mendasari sebagai tujuan dibangunnya bangunan tersebut. Rancangan bangunan tercipta untuk memenuhi kebutuhan manusia yang menggunakan bangunan tersebut. Bentuk hanya mengikuti fungsi, atau dapat berasal dari keinginan pemakai bangunan. [5]

Elemen berikutnya adalah ritme atau irama, dalam hal ini adalah irama sebuah bangunan, biasanya lebih dikenal dengan menyebutnya sebagai pola bangunan. Yang dimaksud di sini adalah sesuatu yang berhubungan dengan perasaan dan emosi, sehingga saat melihat karya seni arsitektur yaitu sosok bangunan, maka dapat dilihat iramanya pada garis-garis vertikal dan horizontal yang terdapat pada fasad bangunan tersebut. Emosi sang arsitek dapat terlihat dari permainan irama atau pola dari unsur-unsur garis vertikal dan horizontal tersebut yang dibentuk dari kolom, pintu, jendela, ornament dan lain-lain. Proporsi adalah elemen yang terakhir yang sangat berperan dalam karya arsitektur. Proporsi berkaitan dengan ukuran yang dilihat dari berbagai aspek. Proporsi juga merupakan keterkaitan antar bagian dari sebuah karya disain atau keterkaitan antara satu unsur dengan unsur lainnya sehingga menghasilkan sebuah disain yang menarik secara estetika. Proporsi digunakan juga sebagai pembanding antar satu bagian dengan keseluruhan bangunan, seperti misalnya dalam disain sebuah pintu sebaiknya harus proporsional terhadap ukuran keseluruhan bangunan, sehingga tidak terjadi ketimpangan baik terlalu kecil maupun terlalu besar ukurannya dibandingkan dengan wujud keseluruhan bangunan.

Terdapat perbedaan mendasar antara karya seni lain dengan arsitektur dalam konteks sebagai karya seni. Kita dapat memilih dan menolak karya seni apapun apabila kita menyukai atau tidak menyukainya. Namun tidak demikian halnya dengan karya arsitektur yang tidak dapat kita tolak, hindari, bahkan kita hilangkan apabila kita tidak menyukainya. Oleh karenanya faktor hati-hati, cermat, dan bertanggungjawab sangat dibutuhkan oleh seorang arsitek jika tidak ingin dipersalahkan apabila rancangannya sedemikian rupa membuat pengguna tidak menyukainya atau merasa terganggu dengan kehadirannya. [4]

\section{KAITAN MUSIK DAN ARSITEKTUR}

Ketika suatu irama dan harmonisasi sangatlah penting dalam dunia seni musik, maka kedua elemen tersebut juga menjadi penting dalam dunia arsitektur. Untuk menghasilkan karya seni musik yang indah tentunya harus memiliki irama dan harmonisasi yang seimbang, begitu juga dengan karya arsitektur, agar tidak menghasilkan karya yang tidak sesuai dengan prinsip arsitektural tentunya irama dan harmonisasi menjadi sangat penting dicermati oleh para pelaku seni musik dan arsitektur. [1]

Ketika sebuah karya arsitektur dihasilkan tentunya tidak jarang musik memiliki peranan penting dalam proses perencanaan dan perancangannya. Musik dapat menjadi sumber inspirasi dalam disain. Hal ini tentunya berkaitan dengan kepekaan antara kedua bidang tersebut yang saling terkait dalam prinsip-prinsip estetikanya baik dalam harmoni, ritme, keseimbangan, penekanan dan lainlainnya. Selain itu tema dan karakter dari sebuah karya seni baik arsitektur maupun musik akan menjadi kunci sebuah proses terjadinya sebuah karya seni. Sebagai contoh saat seorang arsitek menggunakan musik sebagai stimulus dalam proses disainnya, maka hasil akhir disain tersebut tentunya tidak akan jauh berbeda ritme, harmoni dan keseimbangannya dengan jenis musik yang dipilinnya. Kesan psikologis juga akan terbentuk dari proses perencanaan dan perancangan tersebut, sehingga wujud disain yang akan terbentuk akan terintegrasi dengan jenis musik yang dipilinnya. Ketika seorang arsitek memilih musik rock yang berkonotasi maskulin, keras, dinamis dan tidak sesuai aturan, maka disain yang dapat divisualisasikan adalah bentuk disain yang 
dekonstruksi misalnya dengan pemakaian jenis material yang high technology, dengan bahan metal, dominan hitam dan putih dan kemungkinan adanya sedikit warna yang dominan sebagai vocal point (warna merah misalnya), bentuk geometris yang tidak beraturan seperti arsitektur dekonstruksi. [1]

Lain halnya ketika musik yang diperdengarkan adalah musik berirama melankolis, maka ruang yang dapat divisualisasikan tentunya adalah dengan bentuk yang organik menyesuaikan irama musik, dengan warnawarna lembut seperti warna pastel, menggunakan material-material yang minimalis. [1]

Selain kaitan dalam bentuk arsitektur, fluiditas sebuah sirkulasi dalam bangunan arsitektur juga bagaikan alunan sebuah musik, baik yang berliku-liku maupun yang linier, seperti halnya irama dalam sebuah musik. Tata ruang dalam sebuah karya arsitektur juga sangat berkaitan dengan musik, hal ini terlihat dengan gaya maupun warna yang ditampilkan pada interior sebuah bangunan, apakah interior tersebut memperlihatkan kelembutan, arogansi, individualistis ataupun kekakuan, semuanya berkaitan dengan emosional seorang perancang yang tentunya dipengaruhi karena adanya stimulus atau rangsangan dari sebuah alunan musik.

Don Fedorko mengembangkan teori arsitektur dengan menggunakan musik sebagai pendekatan dan sumber inspirasi dalam perancangannya. Dalam diagramnya, ia menginterpretasikan hubungan antara musik dengan arsitektur sebagai berikut. [7]

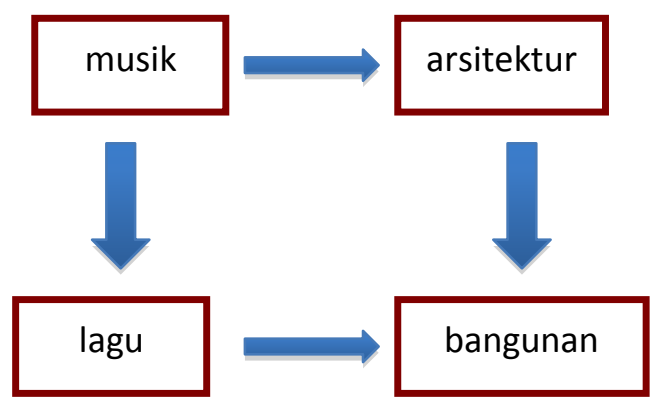

Gambar 4. Diagram Hubungan Musik dan Arsitektur Sumber: Antoniades, 1990
Dari diagram tersebut, dapat diambil suatu benang merah bahwa musik merupakan suatu bentuk atau cara berproses arsitektur, dengan hasil proses berkegiatan tersebut adalah berupa lagu dan bentuk fisik kasat mata berupa bangunan. Sementara itu arsitektur dapat dimaknai sebagai sebuah musik, karena di dalam sebuah karya arsitektur terkandung beberapa elemen yang juga terdapat di dalam musik. Sebuah karya arsitektur dapat terwujud karena adanya kaidah konsep musik, sehingga dapat dikatakan di sini bahwa kaidah-kaidah tersebut mengkaitkan kedua karya seni tersebut yaitu musik dan arsitektur.

Seperti telah dijelaskan pada definisi masingmasing karya seni yaitu musik dan arsitektur, keduanya memiliki unsur-unsur dasar di dalam proses perwujudan idenya. Elemen-elemen dasar kedua karya seni tersebut dapat dikaitkan seperti di bawah ini:

Tabel 1. Hubungan Musik-Arsitektur Dari Elemen Dasar

\begin{tabular}{|c|c|}
\hline MUSIK & ARSITEKTUR \\
\hline Melodi & Komposisi Bentuk \\
\hline Harmoni & Fungsi \\
\hline Ritme & Pola \\
\hline Tempo & Proporsi \\
\hline
\end{tabular}

Sumber: Nindya, 2012

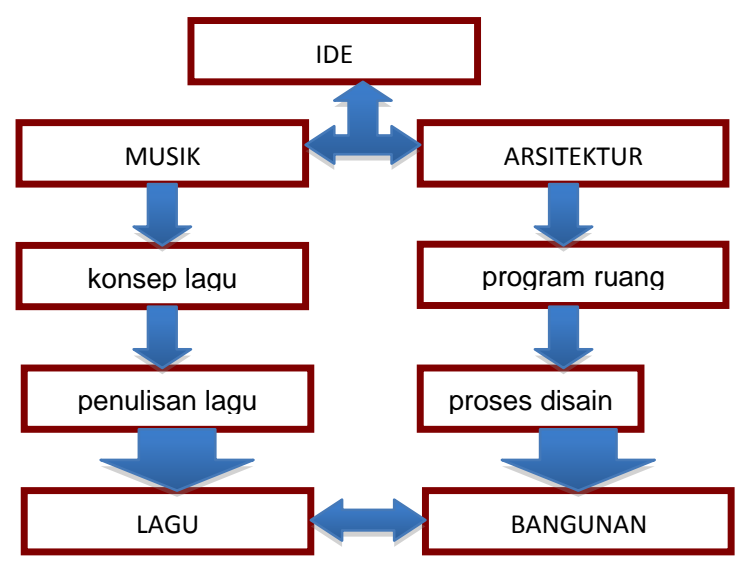

Gambar 5. Diagram Hubungan Musik dan Arsitektur Dalam Proses Perwujudan Karya Seni Sumber: Analisa, 2016

Hal yang sama juga telah dijelaskan sebelumnya, bahwa kedua karya seni yaitu musik dan arsitektur berawal dari sebuah ide yang melalui sebuah proses akhirnya menghasilkan suatu output yang sama-sama merupakan karya seni, walaupun masingmasing berbeda wujud, dalam artian, musik berwujud hal yang tidak kasat mata, dapat didengar oleh indera pendengar, sementara 
arsitektur berwujud sesuatu yang kasat mata yaitu bangunan yang dapat dilihat dengan indera penglihatan. Bila dlihat bagaimana proses keduanya, dapat dilihat dalam gambar 5 di atas.

Selain elemen-elemen dasar yang diperlukan dalam proses perwujudan kedua karya seni baik musik dan arsitektur, maka terdapat juga elemen-elemen penunjangnya. Baik elemen dasar maupun elemen penunjang dari kedua proses perwujudan karya seni tersebut dapat saling dikaitkan satu sama lainnya. Elemenelemen penunjang tersebut dapat dijabarkan sebagai berikut:

Tabel 2. Hubungan Musik-Arsitektur Dari Elemen Penunjang

\begin{tabular}{|c|c|}
\hline MUSIK & ARSITEKTUR \\
\hline Intro & $\begin{array}{c}\text { Pintu masuk/ } \\
\text { entrance }\end{array}$ \\
\hline Bait & Verse/ voyer \\
\hline Refrein & $\begin{array}{c}\text { Major space/ } \\
\text { Ruang utama }\end{array}$ \\
\hline Bridge & $\begin{array}{c}\text { Transit space/ } \\
\text { ruang perantara }\end{array}$ \\
\hline Penutup & Pintu keluar/ exit \\
\hline
\end{tabular}

Ketika pada karya seni musik, alur sebuah musik dimulai dengan intro dan dilanjutkan dengan bait, refrein, bridge dan diakhiri dengan penutup, maka hampir sama untuk karya seni arsitektur. Karya seni arsitektur bila dilihat dari sebuah rancangan pola ruangnya, maka diawali dengan sebuah pintu masuk/ entrance sebagai intronya, dan dilanjutkan dengan verse/ voyer sebagai baitnya, dan kemudian major space atau ruang utama dan transit space atau ruang perantara sebagai refrein dan bridge-nya, yang diakhiri dengan pintu keluar/ exit sebagai penutupnya.

\section{TRANSFORMASI MUSIK DALAM BENTUK ARSITEKTUR}

llustrator dan arsitek asal Italia, Federico Babina dalam mewujudkan keterkaitan musik dan arsitektur, telah merilis seri ilustrasi terbarunya yang berjudul Archimusic, di mana di dalamnya terdapat 27 ilustrasi lagu yang diwujudkan dalam karya arsitektural. Keduapuluh tujuh ilustrasi tersebut diantaranya adalah lagu-lagu dari Miles Davis, Michael Jackson, Amy Winehouse, The Police sampai dengan Nirvana dan The Beatless. [1]

Babina menyatakan bahwa musik dan arsitektur sangat erat kaitannya dalam "cosmic connection", sehingga dalam ilustrasinya tergambar bahwa musik dapat diwujudkan dalam dimensi ruang arsitektur yang berkaitan dengan garis budaya. Warna, irama, harmoni dan nuansa musik yang berbeda dapat membentuk suatu volume dan transformasi bentuk arsitektur yang berbeda juga. Garisgaris horizontal pada karya arsitektur dapat menggambarkan suatu garis melodi dasar, sementara garis-garis vertikal dapat mengilustrasikan suatu harmoni dan disonasi sebuah musik. Sementara bila melihat karya arsitektur yang diilustrasikan oleh Babina, sebuah bangunan seperti halnya perkembangan harmonik yang mengikuti pergerakan chords yang menghasilkan irama yang solid. [1]
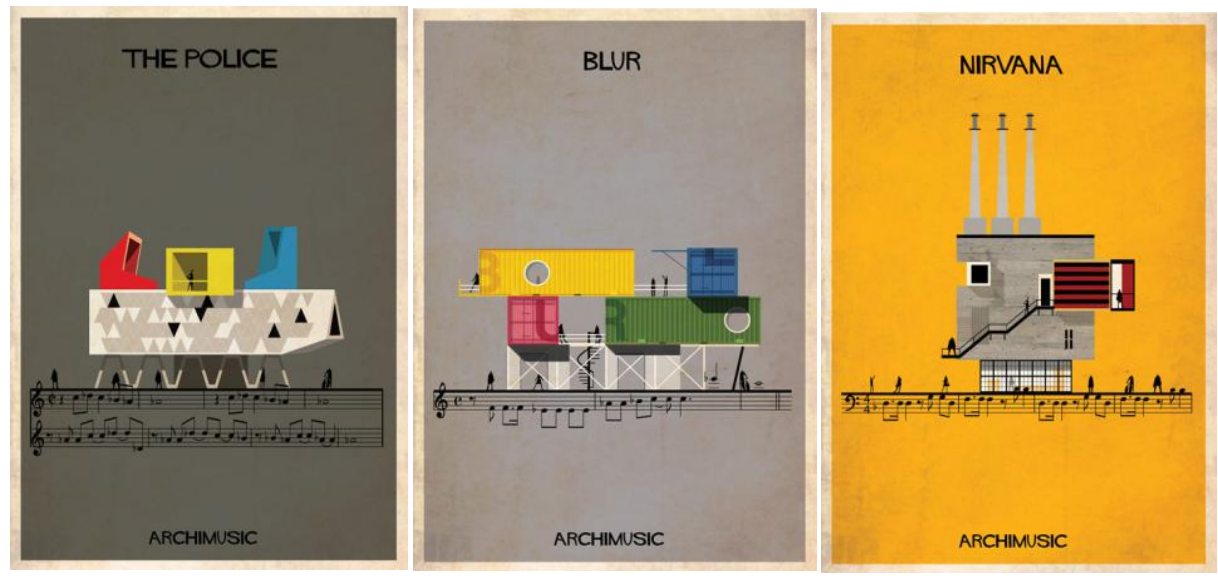
Transformasi musik dalam bentuk arsitektur lainnya dapat dilihat pada karya Le Corbusier dalam mendisain Philips Pavilion Poeme Electronic pada tahun 1958 untuk sebuah eksibisi di Brusel yang dibantu oleh lannis Xenakis seorang arsitek asal Yunani dan juga seorang komposer musik yang saat itu bekerja pada biro konsultan milik Le Corbusier. Saat itu lannis berperan dalam membuat notasi musik untuk mendisain sebuah bangunan yang akan diterapkan oleh Le Corbusier pada karyanya. Hal ini memperlihatkan betapa penting peranan musik dalam proses disain karya arsitektur, karena dalam prosesnya melibatkan aspek psikologis terutama emosi. Pada karyanya, Le Corbusier mencoba mengintegrasikan antara arsitektur, film, pencahayaan dan musik dalam pengalaman total sebuah mahakarya yang melibatkan unsur waktu dan ruang secara bersamaan. Dan hasilnya memang luar biasa, karena bangunan Philips Pavilion mampu menyajikan sebuah fenomena artistik melalui keterpaduan sebuah karya arsitektur, media visual dan musik.

Selain lannis yang juga seorang ahli matematika, Le Corbusier juga dibantu oleh seorang komposer Edgard Varese yang mengkombinasikan kedua unsur musik vokal dan musik konkrit sehingga meningkatkan kedinamisan, pencahayaan dan proyeksi gambar yang disajikan oleh Le Corbusier. Secara visual karya ketiga pelaku seni ini menghasilkan sebuah konsep bentuk yang dinamis dengan pergerakan ruang yang berirama sesuai dengan konsep musik yang dihasilkan lannis. [8]

Namun sayangnya, setahun kemudian pada tahun 1959, seperti bangunan eksibisi lainnya, bangunan karya tiga maestro ini juga bukan merupakan bangunan permanen, sehingga pada tahun ini, bangunan dihancurkan selamanya. Fenomena kaitan musik dan arsitektur yang disajikan pada karya Le Corbusier, lannis Xenakis dan Edgard Varese ini tetap akan menjadi mahakarya mereka.

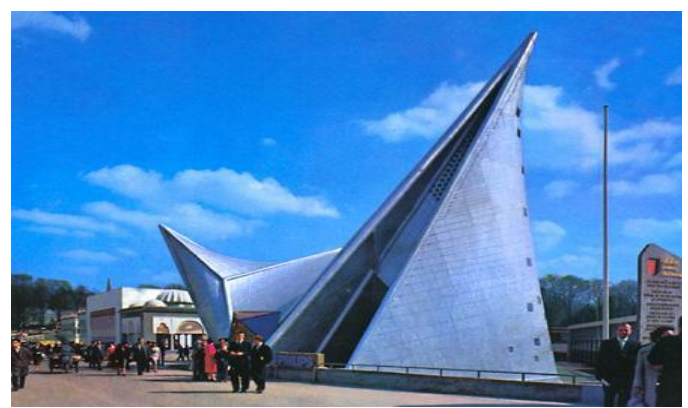

Gambar 7. Philips Pavilion Poeme Electronic Sumber: http://www.medienkunstnetz.de, 2016

Struktur bangunan Philips Pavilion menggunakan struktur cangkang hyperbolicparaboloid, sementara dindingnya merupakan konstruksi dari plat beton yang menggunakan pasir sebagai campurannya. Dengan bentuk yang unik, maka pengerjaan struktur bangunan harus dapat didukung dengan pemilihan material yang tepat. Bentuk rencana denah pada lantai dasar bila dilihat pada gambar berikut (lihat gambar 9 ), memperlihatkan suatu irama tertentu yang mengilustrasikan musik hasil komposisi lannis dan Edgard. Alur sirkulasi bagi pengunjung juga merupakan transformasi dari elemen-elemen penunjang musik dari mulai intro, bait, refrein, bridge sampai dengan penutup, yang diilustrasikan pada denah sebagai sebuah pintu masuk atau entrance, verse atau yang dikenal sebagai voyer, major space adalah ruang utama dari bangunan, transit space yaitu ruang perantara menuju ke arah pintu keluar, pintu keluar atau exit. 


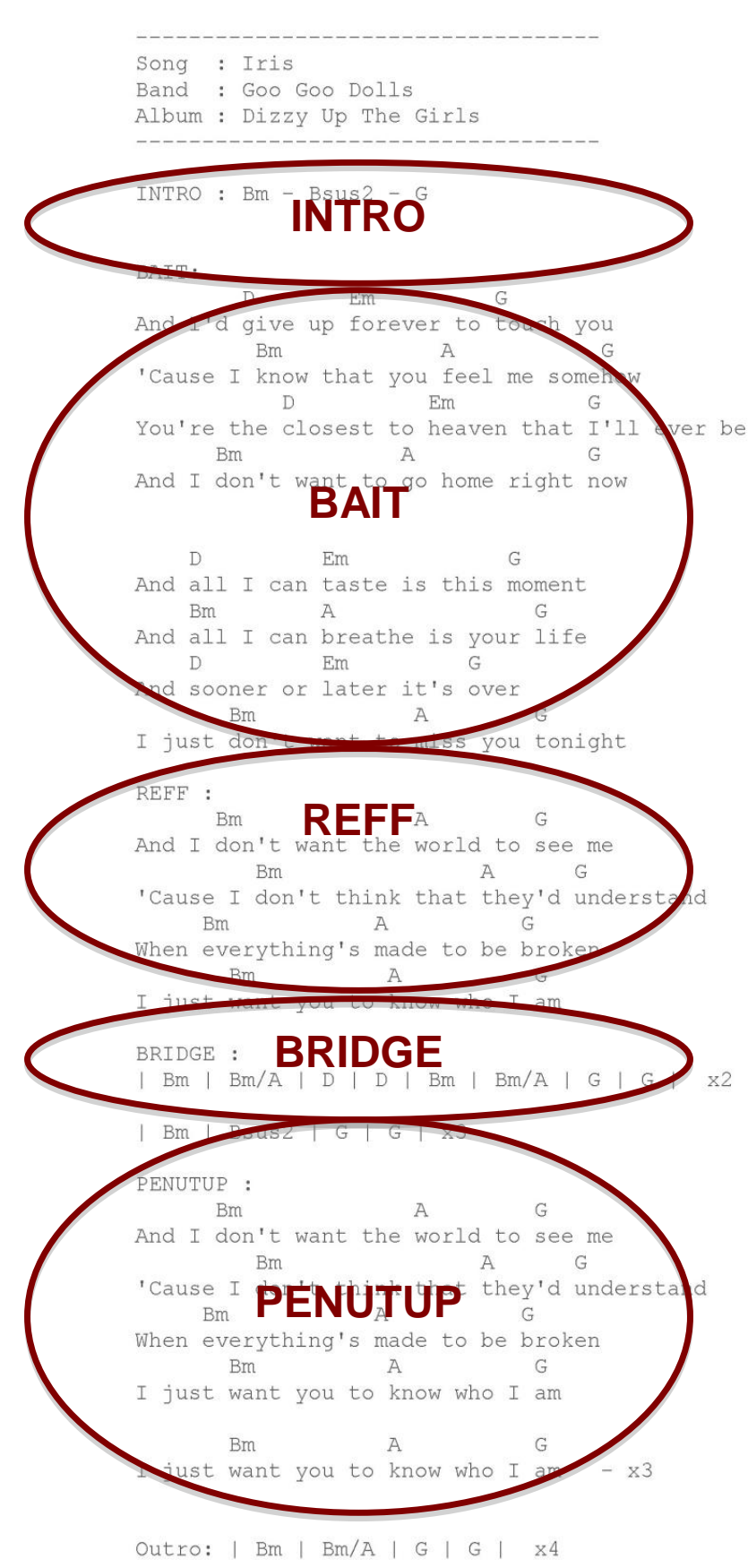

Gambar 8. Struktur sebuah lagu yang dibagi dalam elemen penunjang dari intro, bait, refrein, bridge dan penutup, contoh lagu berjudul Iris dari Goo Goo Dolls Sumber: Analisa, 2016

Ketika proses perwujudan ide tersebut di atas menjadi sebuah lagu seperti lagu Jali-Jali di atas dengan struktur dan alur seperti pada gambar 8 untuk sebuah karya seni musik, maka untuk karya seni arsitektur struktur dan alur dari elemen-elemen penunjangnya dapat dilihat seperti pada gambar 9. Bentuk pengaturan layout pada denah lantai dasar ini yang berliku-liku juga mengibaratkan sebuah irama musik yang memberikan kedinamisan sebuah ruang, sehingga pengunjung tidak bosan untuk melangkah di dalam ruang tersebut.
Proses perwujudan sebuah ide menjadi sebuah karya seni tentunya bukan sebuah proses instan yang terjadi begitu saja, berbagai inspirasi dapat timbul kapan saja, di mana saja dengan ide-ide dan inspirasi yang berbeda-beda tergantung dari stimulus yang merangsang otak dari si pelaku seni. Begitu juga dengan wujud bangunan Philips Pavilion ini juga merupakan sebuah proses dari tiga buah otak pelaku seni yaitu Le Corbusier, lannis dan Edgard yang dipadukan menjadi sebuah mahakarya. 


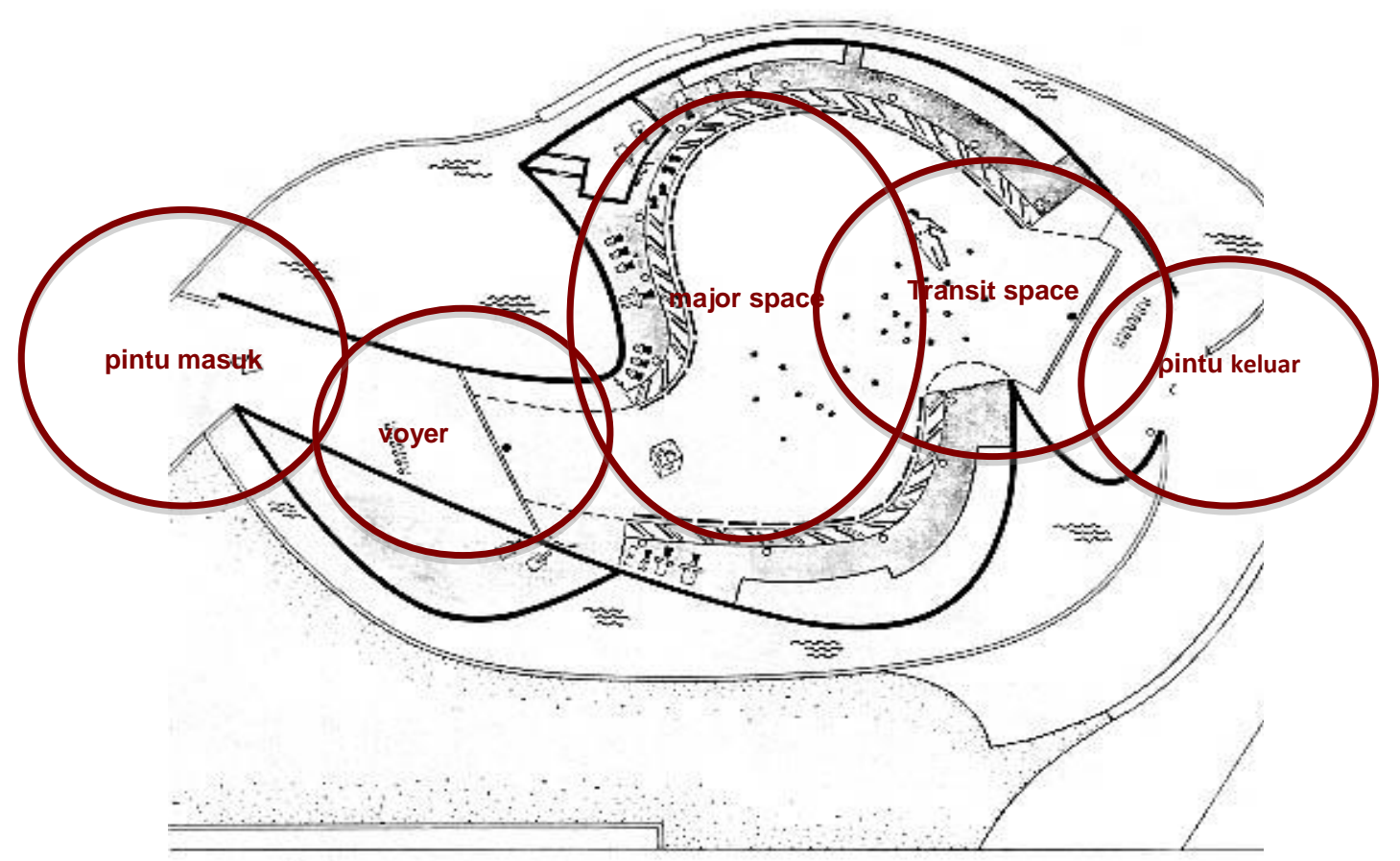

Gambar 9. Denah layout bangunan Philips Pavilion Poeme Electronic dengan pembagian alur ruang berdasarkan elemen penunjang dalam musik dan arsitektur (Sumber: Analisa, 2016)
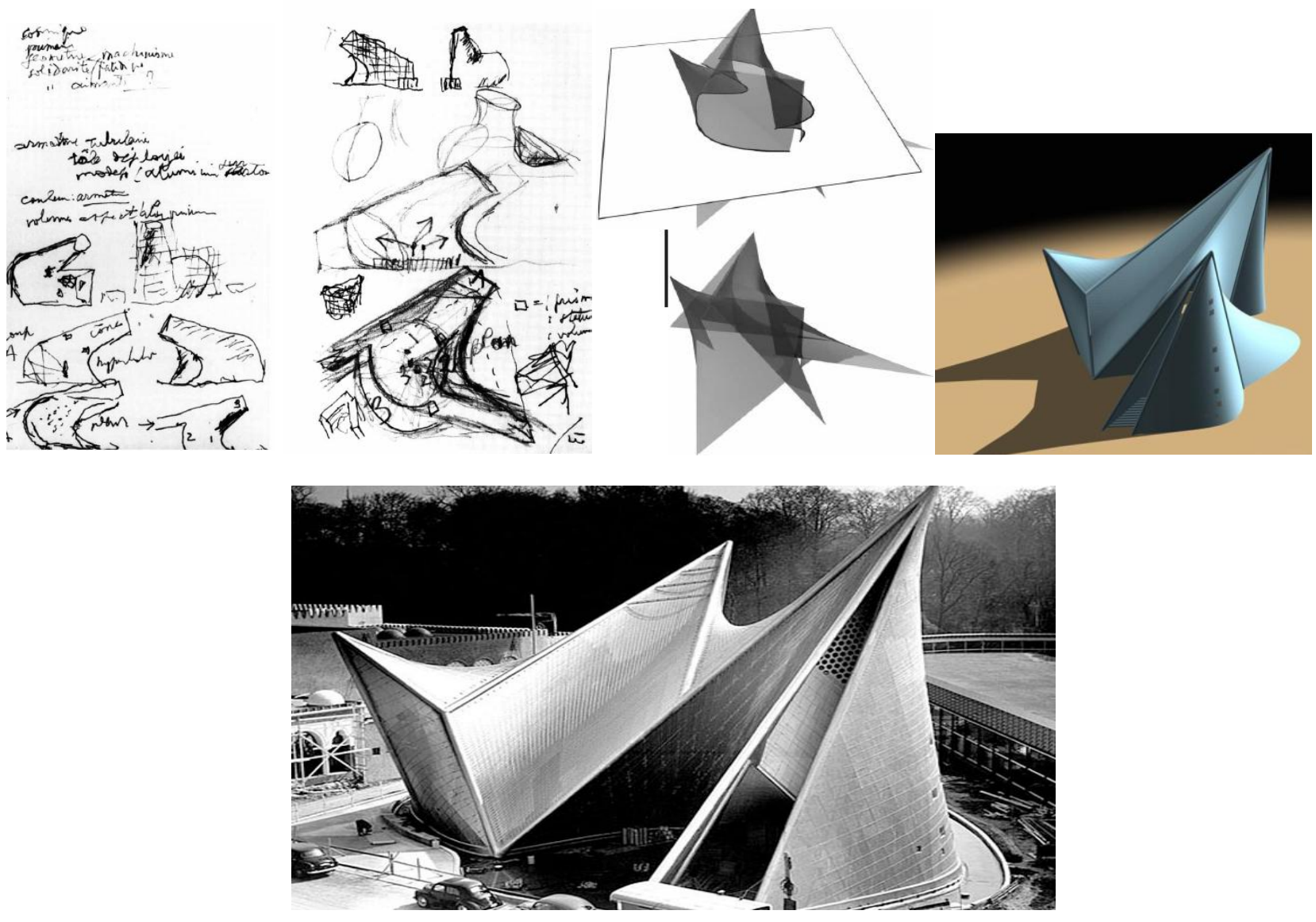

Gambar 10. Proses disain yang terjadi pada perencanaan dan perancangan bangunan Philips Paviliun Poeme Electronic di Brusel (Sumber: archdaily.com, 2016) 


\section{KESIMPULAN}

Keterkaitan antara dua karya seni musik dan arsitektur tidak dapat dipungkiri eratnya. Keduanya memiliki peranan yang besar dalam kehidupan manusia. Saat manusia membutuhkan musik dalam kehidupan seharihari, manusia juga membutuhkan arsitektur sebagai kebutuhan untuk berkegiatan baik berupa ruang aktualisasi diri maupun dalam bentuk lebih besar yaitu rumah, bangunan maupun skala makro lingkungan perkotaan. Kedua karya seni tersebut tidak dapat dipisahkan dalam kehidupan manusia. Keduanya memiliki kesamaan dalam proses perwujudannya, dimana keduanya berawal dari sebuah ide yang kemudia berproses untuk menghasilkan output yang berbeda. Ketika musik berproses dari mulai terbentuknya suatu melodi kemudian menjadi penulisan sebuah lagu, maka hasil akhirnya adalah sebuah karya seni lagu yang tidak dapat dilihat dengan kasat mata namun dapat dinikmati dengan indera pendengar penikmatnya. Lain halnya dengan karya seni arsitektur yang berawal dari ide kemudian berproses dari mulai program ruang sampai dengan proses disain, kemudian menghasilkan hasil akhir berupa karya seni kasat mata yaitu bangunan yang dapat dinikmati oleh indera penglihatan penikmatnya.

Bila dilihat dari unsur-unsur atau elemenelemen karya seni musik dan arsitektur, keduanya memiliki kesamaan yang saling terkait satu sama lain sehingga membentuk suatu karya seni. Pendekatan kedua karya seni tersebut sama, jika dilihat dari elemenelemen pembentuknya. Melihat dari berbagai karya seni arsitektur para arsitek dunia yang dipengaruhi oleh karya seni musik, akan lebih memiliki emosi daripada karya seni arsitektur yang sama sekali tidak dirasuki oleh emosi apapun.

\section{REFERENSI}

[1] Purwantiasning, Ari Widyati \& Djuha, Ahmad Mubarak. Musik Dalam Dimensi Ruang Arsitektur. Republika Online. 04 Februari 2016. Jakarta. 2016

[2] Trancik, Roger. (1086). Finding Lost Space: Theories of Urban Design. June 1986. Amerika.

[3] Zimbardo, Philip G. (1971). Essential Of Psychology And Life. 10th Edition, Hal 283. Usa: Scott, Poresman And Company.

[4] Djuha, Ahmad Mubarak. (2014). Sekolah Tingqi Musik Bertaraf Internasional Di Jakarta Selatan. Jurusan Arsitektur Fakultas Teknik Universitas Muhammadiyah Jakarta. Skripsi. Juni 2014. Jakarta.

[5] Nindya, Stella. (2012). Keterkaitan Musik Dengan Arsitektur. Departemen Arsitektur Fakultas Teknik Universitas Indonesia. Skripsi. Juni 2012. Depok.

[6] Raskin, Eugene. (1954). Architecturally Speaking. Bloch Pub Co. 1st Ed Edition. 1954.

[7] Antoniades, Anthony C. (1990). Music And Architecture. Poetics of Architecture Theory Of Design, Hal. 272. New York: Van Nostrand Reinhold. Amerika. 1990.

[8] Treib, Marc. (1996). Space Calculated In Seconds. Hal. 3. Princenton. Amerika. 1996. 